\title{
Two Opposed Models of Approaching the Relationship between Art and Society and the Proposal of "Social-Aesthetic Constructs" as a Possibility of Mediation
}

\author{
Rodrigo Duarte \\ Faculty of Philosophy and Human Sciences of the Universidade Federal de Minas Gerais (Federal University of Minas Gerais), \\ Belo Horizonte, Brazil \\ Email: rodrigoantonioduarte@gmail.com
}

How to cite this paper: Duarte, R. (2018). Two Opposed Models of Approaching the Relationship between Art and Society and the Proposal of "Social-Aesthetic Constructs" as a Possibility of Mediation. Art and Design Review, 6, 1-11.

https://doi.org/10.4236/adr.2018.61001

Received: July 27, 2017

Accepted: January 22, 2018

Published: January 25, 2018

Copyright $\odot 2018$ by author and Scientific Research Publishing Inc. This work is licensed under the Creative Commons Attribution International License (CC BY 4.0).

http://creativecommons.org/licenses/by/4.0/

\begin{abstract}
The objective of this article is to investigate two opposed models of approaching the relationship between art and society. The first one-that of Jacques Rancière-stresses the idea of aesthetic autonomy as a result of a historical process that began with Kant's Critique of Judgement, reaching its most developed form in contemporaneity, and the second model, represented here by Richard Shusterman (inspired by John Dewey pragmatist aesthetics), focuses on the deep roots that artistic phenomena have in society and culminates with his analysis of the hip hop culture. Taking into account as well their respectively fruitfulness as some of their limitations and inspired by Theodor Adorno, I propose the concept of "social-aesthetic construct", which is meant to be a mediation between the aforementioned opposed models.
\end{abstract}

\section{Keywords}

Jacques Rancière, Richard Shusterman, Theodor Adorno, Autonomy of Art, Social-Aesthetic Constructs

\section{Jacques Rancière and the Dialectic of Aesthetic Separation and Aesthetic Community}

The topic "autonomy of art", which has been discussed since the eighteenth century-almost at the same time of the rise of aesthetics as a philosophical discipline-arrived in the twentieth century to a large extent as a debate on the relationship between art and society. Among the many viewpoints on that rela- 
tionship, I would like to begin my exposition recalling some passages by Jacques Rancière, specifically from his book The Emancipated Spectator. In one of the book's essays, "Aesthetic Separation, Aesthetic Community", the French philosopher quotes a verse by Mallarmé that states: "Apart, we are together" (in French: "Separés, on est ensemble"), referring to the narrative that, in a short boat trip, expecting to see a beautiful young lady on the margin of a river, the poet just listens to her steps behind the bush and then he turns back to his departing point "without either seeing her or being seen by her" (Rancière, 2009: p. 51). Rancière goes further to associate this unconsummated meeting with two famous pictures by George Pierre Seurat, "Bathers at Asnières" and "A Sunday Afternoon on the Island of La Grande Jatte". Both works from the late nineteenth century depict a crowd near a river near Paris and suggest that people are supposed to be simultaneously together and apart. According to Rancière, the literary and the pictorial examples serve as a metaphor of the situation of modern and contemporary art as related to society, which in his own words, suggests "that the very form of the prose poem may have some kind of connection with the painterly conjunction of high art and popular leisure-some kind of relation, I would add, that might itself be a 'distant' relation, as in the relationship between the silent boater and the invisible lady" (Rancière, 2009: pp. 51-52).

As for contemporary art itself, Rancière refers to a project coordinated by young French artists in 2005, called "Urban Encampment", according to which the creation of an "extreme useless, fragile and non-productive" place was to be discussed with the dwellers of a neighborhood of immigrants and poorer people, so that individuals could enter it for the sole purpose of enjoying some kind of loneliness that they could not experience elsewhere in the turbulent quarter. The local participants of the project should also suggest some phrases to be printed in white on black t-shirts to be worn while being photographed and filmed by the artists. Curiously, many of them suggested phrases that recalled Mallarmé's verse "Apart, we are together". Rancière interpreted this act as an aesthetic statement, in which a kind of "dissensus" produced "a new sense of community" (Rancière, 2009: p. 58), associated with what he called elsewhere as "the partition of the sensible" (Rancière, 2004: passim).

Concerning the relationship between "aesthetic separation" and the autonomy of art, in his essay, Rancière brings attention to the positions of some currents of contemporary aesthetics like the modernist narrative of art's promesse $d u$ bonheur and postmodernism's position to it. The mentioned opposition criticizes this view for supposedly being elitist and anti-democratic: "There is the modernist view of the autonomy of the work of art, which more or less loosely connects its 'being apart' with the 'being together' of a future community. [And] there is the postmodernist view that makes 'being apart' an aristocratic illusion aimed at rejecting the real laws of our being together." (Rancière, 2009: pp. 58-59). Before we turn our attention to the views associated to the "real laws of our being together", let us first follow Rancière's discussion a bit further: the 
philosopher emphasizes the difference between the aesthetic conception of the times in which mimesis meant "correspondence between poiesis and aisthesis" (Rancière, 2009: p. 59) and the period posterior to Kant's Critique of Judgment, according to which the absence of concept in the judgment of taste points to a radical disconnection between artists' making artworks and people's enjoying beauty:

It means that there is no longer any correspondence between the concepts of artistic poiesis and the forms of aesthetic pleasure, no longer any determinate relationship between poiesis and aisthesis. Art entails the employment of a set of concepts, while the beautiful possesses no concepts. What is offered to the free play of art is free appearance. This means that free appearance is the product of a disconnected community between two sensoria -the sensorium of artistic fabrication and the sensorium of its enjoyment. (Rancière, 2009: pp. 63-64)

It is very important to my point that what Rancière calls "the aesthetic regime of art" (Rancière, 2009: p. 65; Rancière, 2004: p. 20), which according to him begins with an upheaval of the idea of perfection, has also been worked out in Kant's analysis of the beautiful. There was certainly a very long trajectory between this beginning and Rancierè's "us", which, unfortunately, I won't be able to address here, being the result of this process summarized this way by Rancière himself: "Aesthetic separation (...) implies that there can be no private paradise, that the works are torn away from their original destination, from any specific community, and that there is no longer any boundary separating what belongs to the realm of art from what belongs to the realm of everyday life." (Rancière, 2009: p. 68).

For Rancière, the practical effect of the aforementioned meeting of art and elements of the immediate environment is a more or less conscious willingness of the masses to receive aesthetic information, meaning the advent of a "point where the $u s$ of the community constructed by aesthetic experience meets the us at play in social emancipation" (Rancière, 2009: p. 70). According to him, what is at stake is a refusal by the majority of the population, responsible for work that produces the wealth appropriated by few to go on acting as if neither the doing nor the enjoying artworks were within their reach. In Rancière's own words, "This is what the aesthetic rupture produced: the appropriation of the place of work and exploitation as the site of a free gaze. It does not involve an illusion but is a matter of shaping a new body and a new sensorium for oneself. (...) Aesthetic experience has a political effect to the extent that the loss of destination it presupposes disrupts the way in which bodies fit their functions and destinations." (Rancière, 2009: pp. 71-72).

Facing the potentiality of the rise of a new aesthetic awareness on the part of the excluded and the poor, Rancière mentions several artistic and even urbanistic experiments whose purpose would be to establish conditions for new forms of inclusive communities to arise, all of them depending on some kind of aes- 
thetic thrill to achieve their goals. Despite the good faith and even the aesthetic quality of some of these attempts, according to the French philosopher, there would still be in them something artificial and essentially non-effective, since many of them also unwillingly patronize the communities they were supposed to represent. As an alternative to these experiments that are meant to overcome the "aesthetic separation", Rancière focuses on the works of the Portuguese filmmaker Pedro Costa, who produced an impressive trilogy of semi-fictional movies, shot at Lisbon's peripheral neighborhood Fontainhas, exactly when its poorest huts were about to be demolished:

While relational artists are concerned with inventing some real or fancy monument or creating unexpected situations in order to generate new social relationships in the poor suburbs, Pedro Costa paradoxically focuses on the possibilities of life and art specific to that situation of misery: from the strange coloured architectures that result from the degradation of the houses and demolition itself to the effort made by the inhabitants to recover a voice and the ability to tell their own story amid the effects of drugs and despair. (Rancière, 2009: p. 79)

Even positively evaluating Costa's efforts to show eloquent images of-and also concede voice to-the dwellers of Fontainhas with the remarkable aesthetic quality stressed by Rancière, it would be necessary for the discussion I intend to do, to ask about the aesthetic contributions endeavored by inhabitants of peripheral neighborhoods themselves. If, in addition to that, someone looks for phenomena which happen in peripheral neighborhoods of all the large cities in the Western world, one good answer would point to what is known as "hip-hop culture". As a matter of fact, since the mid seventies many black and marginalized young people all over the world have adopted the lifestyle originated in South Bronx, New York, which encompasses music (DJ-sound), poetry (rap), dance (break dance), visual art ("graffiti") and "The fifth element" (the ideology), besides its unique fashion of clothes, accessories and hairstyle, adding up altogether to a kind of environment I termed elsewhere as "aesthetosphere" (Duarte, 2014).

\section{Richard Shusterman's Apology of "Popular Arts" and Critique of "High Culture"}

Among the efforts to reflect philosophically on hip-hop culture, the most notable is perhaps the one by Richard Shusterman in his book Pragmatist Aesthetics: Living Beauty, Rethinking Art (Shusterman, 2000), which-identified with the post-modern thought pointed out above by Rancière-endeavors to take seriously the aforementioned phenomena, revealing traits of hip-hop culture that make it perhaps the only model of -in a broad sense-political action in which aesthetic manifestations assume a major role. Although Shusterman exposes his criticism against the authors, who, according to him, are champions of "high culture" and enemies of "popular culture" like Adorno, Bourdieu and Clement 
Greenberg, amongst others, before presenting the topics related to his passionate adhesion to hip-hop culture, I am going to invert this order, exposing first his reasons to believe that also under the formal aspect this kind of culture would still be defensible, addressing thereafter briefly Shusterman's critique of Adorno's position, to finally expose my own viewpoint in this quid pro quod.

Before Shusterman enumerates the topics that in his view enable rap to be artistically innovative, he describes this form generally in this way: "rap (...) is a postmodern popular art which challenges some of our most deeply entrenched aesthetic conventions, conventions which are common not only to modernism as an artistic style and ideology but to the philosophical doctrine of modernity and its sharp differentiation of cultural spheres" (Shusterman, 2000: p. 201). Since it is impossible to expose in detail all the traits Shusterman stresses in hip hop culture that would prove it to be also artistically relevant here, I will point out the topics through which he: 1) seeks to show how the "post-modern" language of rap challenges traditional aesthetic concepts; and 2) proposes an aesthetic evaluation of this phenomenon beyond its self-comprehension as "popular art".

As for the first topic, Shusterman draws attention to four items: a) the procedure of sampling as explicit appropriation of well-known materials by anyone, in a sort of continuous cultural recycling; b) the method of creating a montage of constructs instead of composing a conventional artwork in the sense of creating an organic and unified whole; c) the incorporation of technology, due to which rappers, beginning in the condition of mere operators of samplers, turntables, sequencers and other electronic devices, acquire perfection of technique and, therefore, the status of true artists; d) the confrontation of aesthetic autonomy through which the adepts of the more ideological rap, termed "knowledge rap", declare that, rather than to be considered artists in a conventional sense, they are vehicles of social transformation through their contribution to the increase of political consciousness in their communities.

In his second topic, Shusterman approaches primarily what he believes to be the richness of language of a rap, “Talkin' all that jazz”, in which the philosopher identifies several layers of meaning, beginning with the ambiguity of the word "jazz" already in the title of the song. According to him, the codification and the establishment of multiple levels of meaning lie nevertheless in the most representative raps of this genre:

It also, of course, helped make the black community especially adept and familiar with the encoding and decoding of ambiguous and inverted messages. Rap fans, then, through their ordinary linguistic training, have typically mastered a wittily indirect communicative skill which one researcher regards as "a form of verbal art", and which enables them to readily process texts of great semantic complexity if the content is relevant to their experience. (Shusterman, 2000: p. 222; Michell-Kernan, 1972)

In addition to the qualities to be virtually found in rap, beyond the aforemen- 
tioned expressive and formal elements, Shusterman questions a possible philosophical density in many of its texts, in which the most immediate level of language hides very complex meanings. From an analysis that confronts the common sense of what is said with possible deeper senses, Shusterman stresses the idea of saying something as a form of political action and a reflection on the association of beauty with the color of the skin, since the expression "skin deep" refers to "superficiality".

Having insufficient space to expose the whole of Shusterman's analysis of hip-hop culture, I shall shift now to the presentation of his arguments against the viewpoint commonly associated to the so-called "high culture". The first one concerns the fact that, since artists were (and to a certain extent still are) traditionally sponsored by the richest people, their works have often responded to the requests of the ruling classes rather than to those of the poorer majority of society including their interest in overcoming economic inequality and social injustice. According to him, "Art thus provides an oppressive conservative establishment with a most powerful weapon to sustain existing privilege and domination, to affirm the status quo and the past which engendered it, despite all the misery and injustice they contain" (Shusterman, 2000: p. 141).

Shusterman's second topic in his chastising of high art-as a matter of fact, a variation of the first topic-is its alleged misuse as a means of distinguishing the upper classes from the lower ones, since the masses, generally speaking, would not master the necessary cultural presuppositions for its enjoyment. As to the possible "humanistic" answer to this indictment, according to which efforts should be made, so that the masses will acquire the means to understand these more complex artforms, Shusterman states that high arts' very logic does not allow it to be popularized in a short term, so that it should remain at least for a long time as a class differentiating element.

The third type of moral restriction to "high art" is based on the fact that, when such art reaches wider portions of the population, it works as a part of dominant ideology, since it constitutes a world of beauty and plenitude, but just in an ideal -not material-sense, being able to co-exist with acute economic poverty and social misery.

In his attempt to take some phenomena of "popular culture" seriously, beyond pointing out these three kinds of ethical restriction to "high art", Shusterman mentions four items that, historically, made the approach to his object difficult. The first one is the fact that the defense of popular art must be done mainly across enemy line, since the theoretical discussion has been solidary with high culture, rather than to popular culture. Secondly, when intellectuals fight for "popular culture", they take into account its aesthetic deficiencies as if they were precisely their main virtues. The third difficulty is, according to Shusterman, the tendency to consider erudite art only in its most spectacular expressions, setting aside inferior artworks, which might present formal insufficiencies even more relevant than the ones of some pieces of popular culture. Finally, the fourth difficulty is that the very idea of an aesthetics dedicated to popular culture would 
appear as a contradiction in itself, since its constructs allegedly would not deserve an analysis of the type traditional aesthetics is accustomed to.

But, according to Shusterman, the high art's establishment is not just passive in rejecting popular art, but makes at least four groups of restrictions directed specifically towards mass culture, as compiled by Herbert Gans (Gans, 1974). The first one concerns the fact that mass culture comes from an industry that endeavors just profiting from its standardized products, imposed from top down. The second group of restrictions to mass culture points to its pernicious affront on high culture, since the former borrows its contents from the latter, mostly without making it explicit and, thanks to its easiness of assimilation-also a result of its omnipresence-takes a much larger space than the "serious arts" do. The third group of accusations against mass culture concerns the undesirable effects it causes on its audience. In Herbert Gans own words, "popular culture is emotionally destructive because it produces spurious gratification... it is intellectually destructive because it offers meretricious and escapist content which inhibits people's ability to cope with reality; and... it is culturally destructive, impairing people's ability to partake of high culture" (Gans, 1974: p. 30). The fourth and last group approaches mass culture's potentiality to generate passivity in the social realm, predisposing people to accept authoritarian and even totalitarian political viewpoints. Although Gans' viewpoint seems to be too schematic and even naive, when compared to Horkheimer and Adorno's, Shusterman does not spare criticism to their analysis of "culture industry" in the Dialectic of Enlightenment. Even if he admits, for instance, certain intellectual passivity in mass culture audience, Shusterman sharply disagrees that mental effort be the main criterion for aesthetic legitimacy, pointing out the somatic activity as possibly more relevant to it:

Much popular art may indeed conform to Horkheimer and Adorno's analysis. But their critique also betrays the simplistic conflation of all legitimate activity with serious thinking, of "any effort" with "mental effort" of the intellect. Critics of popular culture are loath to recognize that there humanly worthy and aesthetically rewarding activities other than intellectual exertion. So even if all art and aesthetic enjoyment do indeed require some active effort or the overcoming of some resistance, it does not follow that they require effortful "independent thinking". There are other, more somatic forms of effort, resistance, and satisfaction. (Shusterman, 2000: pp. 183-184)

Although Shusterman's point of view on the relevance of bodily activities may deserve attention, it does not mean that all the criticism of Adorno's reasoning is unquestionably adequate. Furthermore, in spite of his recognition of Adorno's work and even some statements about a possible affinity between the Critical Theory of Society and pragmatist aesthetics, one can find in Shusterman's analysis some major misinterpretations concerning Adorno's critique of culture industry. 


\section{Critique to Shusterman's Viewpoint}

The first critical mistake I see in Shusterman's position, which appears, as a matter of fact, in many theoreticians based in the United States, is not differentiating between popular art and culture industry. The realm of the popular culture, properly speaking, is composed mostly of very simple creations, but almost always with a high density and authenticity, since they are not-as cultural commodities are-manufactured in order to satisfy a demand, although they spontaneously express a latent desire of the community in which they appear. On the other hand, culture industry must be understood as a characteristic domain of late capitalism, according to which the advent of technological means of production and diffusion of audiovisual media allowed the rise and development of a sui generis model of ideology, in whose realm discourse is progressively substituted with images and sounds (either isolated or articulated to each other) and the adhesion by the masses to viewpoints of the ruling classes is meant ultimately by the purchase of commodities, what strengthens not only their producers and the culture industry as a whole, but all the economic system from which it arose.

It is worth considering that Horkheimer and Adorno do not themselves use the expression "popular culture" in the Dialectic of Enlightenment, since the Nazis in the thirties and early fourties misappropriated the German term völkisch-popular-, which implied in the adoption, by the authors, of the expression leichte Kunst (light art) (Adorno \& Horkheimer, 1996: p. 135) to designate the aforementioned art made by the people on their own behalf-the same as is meant today by "popular art". We can now affirm this point, because in an essay of the sixties, termed "Culture Industry Reconsidered", Adorno himself exposed his distinction between popular culture and culture industry, as well as their specific relationship to the erudite culture:

In our drafts we spoke of "mass culture". We replaced that expression with "culture industry" in order to exclude from the outset the interpretation agreeable to its advocates: that it is a matter of something like a culture that arises spontaneously from the masses themselves, the contemporary form of popular art. From the latter the culture industry must be distinguished in the extreme. The culture industry fuses the old and familiar into a new quality. In all its branches, products which are tailored for consumption by masses, and which to a great extent determine the nature of that consumption, are manufactured more or less according to plan. The individual branches are similar in structure or at least fit into each other; ordering themselves into a system almost without a gap. This is made possible by contemporary technical capabilities as well as by economic and administrative concentration. The culture industry intentionally integrates its consumers from above. To the detriment of both it forces together the spheres of high and low art, separated for thousands of years. The seriousness of high art is destroyed in speculation about its efficacy; the seriousness of the 
lower perishes with the civilizational constraints imposed on the rebellious resistance inherent within it as long as social control was not yet total.

(Adorno, 1991: p. 98) ${ }^{1}$

The disregard of the difference between popular culture and culture industry is one of the major weaknesses of Shusterman's "pragmatist aesthetics", although there are a lot of other mistakes that threaten his generous and even necessary proposal to positively evaluate popular art. I am going to mention here just the one of these problems that seems to me the most relevant: it concerns the criticism to the erudite art, according to which it would be the immediate reflex of the will of the ruling class in detriment of the majority of the population. For Horkheimer and Adorno, although "high art" was ordered and sponsored by the bourgeoisie, it contained in itself-encapsulated in its very form-a deep critique to the status quo and a message of emancipation for the whole humankind, in the same sense of what Rancière defined above as "the modernist view of the autonomy of the work of art, which more or less loosely connects its 'being apart' with the 'being together' of a future community" (Rancière, 2009: pp. 58-59). In a passage from Dialectic of Enlightenment, Adorno and Horkheimer express exactly what is at stake here:

The purity of bourgeois art, which hypostasized itself as a world of freedom in contrast to what was happening in the material world, was from the beginning bought with the exclusion of the lower classes-with whose cause, the real universality, art keeps faith precisely by its freedom from the ends of the false universality. (Adorno \& Horkheimer, 1996: p. 135)

\section{Proposal of the "Social-Aesthetics Constructs" as a Mediating Concept}

Just these two of Shusterman's mistakes concerning his interpretation of Horkheimer and Adorno's critique to mass culture-the confusion between the latter and popular culture and the identification of bourgeois art immediately with the ideology of the ruling classes-would be enough to question the core of his analyses, in spite of his benevolent attempt to consider hip hop culture as a cultural object to be taken seriously. The question to be posed is: would it be really necessary and indispensable for us to "buy" all his questionable points to make hip hop culture an object of a profound philosophical reflection? There is still another question related to this: Presupposing Adorno's sympathy for erudite art, would it be impossible to approach phenomena, such as the hip hop culture, fairly from the position established in his Critical Theory of Society?

\footnotetext{
${ }^{1}$ Adorno makes a very eloquent defense of the possible intertwining of popular and erudite culture in his essay "On Lyric Poetry and Society", according to which: "Romanticism's link to the folksong is only the most obvious, certainly not the most compelling example of this. For Romanticism practices a kind of programmatic transfusion of the collective into the individual through which the individual lyric poem indulged in a technical illusion of universal cogency without that cogency characterizing it inherently. Often, in contrast, poets who abjure any borrowing from the collective language participate in that collective undercurrent by virtue of their historical experience." (Adorno, 1991a: p. 45)
} 
The answer to the first question is simply: "no". To the second, the response is also "no", but we must nevertheless remember that, for Horkheimer and Adorno, popular culture is not an evil in itself and in fact deserves all respect. However, since it does not possess the formal strength of erudite art, it is more vulnerable to the attacks or even the patronizing of the culture industry and, in the form it existed since immemorial times, it tends to perish, where it still subsists in some extent.

Phenomena, like the hip-hop culture, on one hand, are not typical products of the culture industry, because they are not tailored to consumption, but really express desires and expectations of the communities from which they arise and, as a matter of fact, chastise capitalism and other processes of social exclusion as racism, for instance. On the other hand, even with all the efforts of Shusterman to prove the contrary, these phenomena do not possess the formal traits, thatas it occurs in erudite art-serve as an obstacle to its misappropriation by the culture industry. Then hip-hop culture must be understood as a model of culture that is neither completely industrialized nor "pure" as bourgeois art was meant to be. And it is also not authentically "popular", as the aforementioned type of culture, which is still possible to find almost only in agricultural regions of the modern world and is, unfortunately, condemned to disappear.

In face of the difficulty of applying the concepts related to the mentioned three models of culture-popular culture, culture industry and erudite culturefor phenomena like the hip-hop culture, it is necessary to conceive a fourth model that contains elements of the three types, without being appropriately designated by any of them isolated from the others. The hip-hop culture displays the same kind of appropriation of technology of mass culture, although its actors' relationship to the culture industry itself is everything but passive. Furthermore, what hip-hop culture inherits from the authentic popular culture is its true calling to express the expectations of its community; from erudite art, it inherits the ability to project the possibility of emancipation of the whole of humanity-the "universality" implied by Horkheimer and Adorno-even if it comes from a particular group in society.

I termed this fourth model elsewhere (Duarte, 2007) as "social-aesthetic construct", meaning the cultural phenomena, whose content (not their form, as Horkheimer and Adorno demands from erudite art) and whose appropriation of technology (differently from culture industry) are critics to capitalism. Like authentic popular culture, this kind of aesthetic constructs expresses genuinely the spiritual needs of its community, without being too strongly attached to the traditional communities from the backlands. With this proposal, I think to reckon with Rancière's demand, that "The critical model entailed a specific mediationthe production of awareness-between the 'being apart' of the work and the 'being together' of a new community" (Rancière, 2009: p. 76).

\section{References}

Adorno, T. W., \& Horkheimer, M. (1996). Dialectic of Enlightenment. New York: Con- 
tinuum.

Adorno, T. W. (1991). Culture Industry Reconsidered. In: J. M. Bernstein (Ed.), The Culture Industry. Selected Essays on Mass Culture. London and New York: Routledge.

Adorno, T. W. (1991a). Notes to Literature (Volume One). S. W. Nicholsen (Trans.). New York: Columbia University Press.

Duarte, R. (2007). Sobre o construto estético-social. Sofia, XII, 17\&18, 239-246.

Duarte, R. (2014). Vilém Flusser e a estetosfera brasileira. In: R. Duarte, A. Serra, \& R. Freitas (Eds.), Imagem, imaginação, fantasia. Vinte anos sem Vilém Flusser (pp. 177-189). Belo Horizonte: Relicário Edições.

Gans, H. J. (1974). Popular Culture and High Culture: An Analysis and Evaluation of Taste. New York: Basic Books.

Michell-Kernan, C. (1972). Signifying, Loud-Talking and Marking. In: T. Kochman (Ed.), Rappin' and Stylin' Out (pp. 326-327). Urbana: University of Illinois Press.

Rancière, J. (2004). The Politics of Aesthetics. The Distribution of the Sensible. New York/London: Continuum.

Rancière, J. (2009). Aesthetic Separation, Aesthetic Community. In: G. Elliot (Trans.), The Emancipated Spectator (pp. 51-82). London: Verso.

Shusterman, R. (2000). Pragmatist Aesthetics. Living Beauty, Rethinking Art. Lanham/Boulder/New York/London: Rowman \& Littlefield Publishers. 